University of Nebraska - Lincoln

DigitalCommons@University of Nebraska - Lincoln

Faculty Papers and Publications in Animal

Science

Animal Science Department

1958

\title{
Grain Sorghum for Growing-Finishing Swine
}

E. R. Peo, Jr.

University of Nebraska-Lincoln

D. B. Hudman

Nebraska Agricultural Experiment Station

Follow this and additional works at: https://digitalcommons.unl.edu/animalscifacpub

Part of the Animal Sciences Commons

Peo, Jr., E. R. and Hudman, D. B., "Grain Sorghum for Growing-Finishing Swine" (1958). Faculty Papers and Publications in Animal Science. 621.

https://digitalcommons.unl.edu/animalscifacpub/621

This Article is brought to you for free and open access by the Animal Science Department at DigitalCommons@University of Nebraska - Lincoln. It has been accepted for inclusion in Faculty Papers and Publications in Animal Science by an authorized administrator of DigitalCommons@University of Nebraska - Lincoln. 


\title{
GRAIN SORGHUM FOR GROWING-FINISHING SWINE ${ }^{1}$
}

\author{
E. R. Peo, JR. ANd D. B. Hudman \\ Nebraska Agricultural Experiment Station, ${ }^{2}$ Lincoln
}

$\mathrm{C}$

ONSIDERABLE research has been conducted on the feeding value of

grain sorghums for swine. Baker and Reinmiller (1939) observed that for the production of gains, grain sorghums were equal to or better than corn but considerable more feed was required to produce a pound of gain with the sorghums. Loeffel (1957) summarized several Nebraska swine experiments and observed that grain sorghum and corn produced approximately the same average daily gain, but, in general, 10 to $20 \%$ more feed was required per pound of gain with the grain sorghum. Similar results have been reported by Aubel $(1950,1954,1955,1956)$ and Hillier et al. (1954).

For the most part, only the standard varieties of grain sorghums have been studied in swine rations. Also, the rations used in the early studies were not as highly fortified as are our present ones. For these reasons experiments were conducted to compare the feeding value of certain standard and hybrid varieties of grain sorghum with corn when fed either as the entire, or as a part of, the grain portion of well-fortified swine rations.

\section{Experimental Procedure}

Experiment 1. Two hundred and twenty-four purebred Yorkshire, purebred Hampshire and Yorkshire-Hampshire crossbred pigs which averaged $56.5 \mathrm{Ib}$. live weight were alloted at random to four replications of eight experimental treatments on the basis of breeding and weight outcome groups. The pigs were housed in concrete-floored pens that were equipped with self-feeders and waterers. The pens were cleaned daily and straw was used for bedding.

The experimental ration treatments were as follows: Corn. (1) $8.5 \%$ protein corn; (2) $11.0 \%$ protein corn. Grain sorghum varieties. (3) Martin; (4) Reliance; (5) Hybrid RS 590; (6) Hybrid RS 650; (7) Hybrid RS 501; (8) Hybrid RS 610. A brief agronomic description of the hybrid grain sorghums is as follows:

Hybrid RS 590 is a cross between $m s$ (male sterile) Combine Kafir-60 $X$ Redbine 60 . It is one to two days earlier than Martin (Martin blooms

\footnotetext{
1 Published with the approval of the Director as Paper No. 868, Journal Series, Nebraska Agricultural Experiment Station.

2 Department of Animal Husbandry. Acknowledgment is made to P. F. Cunningham and associates for assistance in caring for the experimental animals and to Merck and Company, Inc., Rahway, New Jersey, and to Lederle Laboratories Division, American Cyanamid Company, Pearl River, New York for certain of the experimental ingredients.
} 
in approximately 67 days). IIybrid $R S 650$ is a cross between $m s$ Combine Kafir- $60 \times$ Plainsman. It heads in about the same number of days as Martin. Iybrid RS 501 is a cross between ms Combine Kafir-60X Norghum. This is the earliest hybrid, maturing about 2 or 3 days later than Reliance (Reliance blooms in approximately 55 days). Hybrid $R S$ 610 is a cross between $m s$ Combine Kafir-60×Combine 7078. It is approximately 3 days earlier in heading than Martin.

Since standard corn is usually lower in protein than milo, one treatment consisted of a medium protein corn which contained about the same amount of protein as milo (calculated as $11 \%$ ). The corn and milo were coarsely

TABLE 1. COMPOSITION OF EXPERIMENT RATIONS

\begin{tabular}{|c|c|c|c|}
\hline Ration designation ${ }^{n}$ & Regular corn & Medium corn & Milo \\
\hline \multicolumn{4}{|l|}{ Ingredients, lb. } \\
\hline Ground yellow corn & 79.4 & $\ldots$ & $\ldots$ \\
\hline Ground yellow corn (medium protein) & $\ldots$ & 85.4 & $\ldots$ \\
\hline Ground milo (all varieties) & $\ldots$ & $\ldots$ & 85.7 \\
\hline $50 \%$ meat and bone meal & 2.5 & 2.5 & 2.5 \\
\hline $17 \%$ dehydrated alfalfa meal & 2.5 & 2.5 & 2.5 \\
\hline $44 \%$ solvent soybean oil meal & 12.6 & 6.6 & 6.5 \\
\hline Ground limestone & 0.5 & 0.5 & 0.7 \\
\hline Steamed bone meal & 0.9 & 0.9 & 0.5 \\
\hline Salt (iodized) & 0.5 & 0.5 & 0.5 \\
\hline Trace minerals (high zinc, swine) & 0.1 & 0.1 & 0.1 \\
\hline Vitamin-antibiotic premix & 1.0 & 1.0 & 1.0 \\
\hline
\end{tabular}

a Calculated protein content, $14 \%$.

b Contributed the following amounts of vitamins and antibiotics per pound of complete ration: Vit. D2, 300 I.U.; riboflavin, $2.2 \mathrm{mg}$.; niacin, $6.0 \mathrm{mg}$; calcium pantothenate $3.0 \mathrm{mg}$; choline chloride, $110 \mathrm{mg} . ;$ Vit. B $12 \mathrm{mcg}$; and antibiotics, $5 \mathrm{mg}$.

ground by a burr mill and were fed in completely mixed rations. The composition of these rations is presented in table 1 . The experiment was terminated after 49 days (average final pig weight, $128.8 \mathrm{lb}$.) because of a limited supply of certain of the hybrid varieties.

Experiment 2. Seventy-five crossbred pigs (Hampshire $\mathrm{x}$ Yorkshire or the reciprocal cross) which averaged $47.7 \mathrm{lb}$. live weight were allotted at random by weight outcome groups to three replications of five experimental treatments. Housing and management were essentially the same as previously described for the first experiment.

The experimental rations and their respective compositions are presented in table 2. As indicated by the ration treatments, one-third, twothirds and all of the corn in the basal ration was replaced with grain sorghum (Martin variety). In these particular treatments all other ration components were held at a constant level. The basal ration (all corn) calculated $14 \%$ protein whereas in the other rations, where corn was replaced with grain sorghum, the protein content increased progressively to a total 
of $16 \%$ for the ration (treatment 4 ) in which all of the corn was replaced with grain sorghum on a pound for pound basis. In addition, one experimental treatment (treatment 5) consisted of an all grain sorghum ration calculated to contain $14 \%$ protein for a comparison with the $14 \%$ allcorn ration and the other ration treatments. The corn and grain sorghum were ground with a burr mill and fed in completely mixed rations. The experiment was terminated after 70 days.

TABLE 2. COMPOSITION OF EXPERIMENTAL RATIONS

(Experiment 2)

\begin{tabular}{|c|c|c|c|c|c|}
\hline Treatment & 1 & 2 & 3 & 4 & 5 \\
\hline Ration designation ${ }^{a}$ & $\begin{array}{c}\text { All } \\
\text { corn }\end{array}$ & $\begin{array}{l}2 / 3 \text { corn } \\
1 / 3 \text { milo }\end{array}$ & $\begin{array}{l}1 / 3 \text { corn } \\
2 / 3 \text { milo }\end{array}$ & $\begin{array}{c}\text { All } \\
\text { milo }\end{array}$ & $\begin{array}{c}\text { All } \\
\text { milo }\end{array}$ \\
\hline \multicolumn{6}{|l|}{ Ingredients, $\mathrm{lb}$. } \\
\hline Ground yellow corn & 79.4 & 53.2 & 26.2 & $\cdots$ & $\cdots$ \\
\hline Ground milo (Martin) & $\ldots$ & 26.2 & 53.2 & 79.4 & 85.7 \\
\hline $44 \%$ solvent soybean oil meal & 12.6 & 12.6 & 12.6 & 12.6 & 6.5 \\
\hline $50 \%$ meat and bone meal & 2.5 & 2.5 & 2.5 & 2.5 & 2.5 \\
\hline $17 \%$ dehydrated alfalfa meal & 2.5 & 2.5 & 2.5 & 2.5 & 2.5 \\
\hline Ground limestone & 0.5 & 0.5 & 0.5 & 0.5 & 0.7 \\
\hline Steamed bone meal & 0.9 & 0.9 & 0.9 & 0.9 & 0.5 \\
\hline Salt (iodized) & 0.5 & 0.5 & 0.5 & 0.5 & 0.5 \\
\hline Trace minerals (high zinc, swine) & 0.1 & 0.1 & 0.1 & 0.1 & 0.1 \\
\hline Vitamin-antibiotic premix ${ }^{b}$ & 1.0 & 1.0 & 1.0 & 1.0 & 1.0 \\
\hline
\end{tabular}

a Calculated protein content $14.0,14.6,15.3,16.0$ and $14.0 \%$, respectively.

b Contributed the following amounts of vitamins and antibiotics per pound of complete ration: Vit. D2, 300 I.U.; riboflavin, $2.2 \mathrm{mg}$; niacin, $6.0 \mathrm{mg}$; calcium pantothenate, $3.0 \mathrm{mg}$; choline chloride, $110 \mathrm{mg}$; Vit. $B_{12}, 5 \mathrm{mcg}$; and antibiotics, $5 \mathrm{mg}$.

In both experiments, pig weight and feed data were collected at twoweek intervals. The Q-test (Snedecor, 1956) was used to test for significance between treatment means. All statements concerning statistical significance are at a probability level of $5 \%$ or less.

\section{Results and Discussion}

Experiment 1. The results of this experiment are presented in table 3 . The greatest average daily gain was made by pigs fed the ration of regular $(8.5 \%)$ protein corn. However, this gain was not significantly different from the average daily gains made by pigs fed Martin, Reliance, Hybrid RS 590, Hybrid RS 650 or Hybrid RS 501 grain sorghum rations. The average daily gains made by pigs fed medium (11\%) protein corn and Hybrid RS 610 were significantly less than those made by pigs fed the other rations.

The poor performance of pigs fed medium protein corn may have been caused by either or both of the following factors. First, Frey (1951) has shown that when the protein content of corn is increased genetically, zein 
becomes an increasing proportion of the total protein. Since apparently all the proteins (and consequently amino acids) in corn are not increased uniformly, the possibility for the occurrence of an amino acid imbalance and/or deficiency in swine rations may increase through the use of medium protein corn. Second, the medium protein corn was 2 years old and, therefore, perhaps was not as digestible as the new-crop regular $(8.5 \%)$ protein corn; $0.15 \mathrm{lb}$. more feed was consumed per day by the pigs fed medium protein corn.

TABLE 3. COMPARISON OF CORN AND CERTAIN VARIETIES OF GRAIN SORGHUM FOR GROWING-FINISHING SWINE "

a Duration of test, 49 days. One pig from each of treatments 3 and 4 removed because of hernia.

Dean difference significant at $\mathrm{P}=0.05$ or less.

c Means underlined by the same line are not significantly different at $\mathrm{P}=0.05$ or less.

The poor gain performance of the pigs fed Hybrid RS 610 can be attributed (in part at least) to a reduced feed intake. Aubel (1951) and Hillier and associates (1954) observed considerable differences in the palatability of several grain sorghum varieties. A difference in tannic acid content may account for such difference in palatability. Apparently Hybrid RS 610 was less palatable than the other grain sorghums (if feed consumption is used as an index of palatability) since the pigs ate less of this variety.

Pigs fed regular protein corn required significantly less feed per pound of gain than those fed the other rations (table 3 ). Significantly less feed was required per pound of gain with rations containing Hybrids RS 501, 610, 650 and Reliance than with Martin, medium protein corn and $\mathrm{Hy}$ brid RS 590. The pigs fed Hybrid RS 590 required the most feed (3.93 lb.) per pound of gain. The difference between this value and the values for the other ration treatments was significant.

Experiment 2. The results of this experiment are presented in table 4 . The pigs on the grain ratio of $1 / 3$ corn and $2 / 3$ milo (treatment 3 ) made an average daily gain of $1.86 \mathrm{lb}$. This gain was significantly greater than the gains made by pigs subjected to the other ration treatments except treatment 1 , the all-corn ration. 
Pigs on ration treatment 1 gained $1.80 \mathrm{lb}$. per day, which was not significantly different from the gain by pigs on treatments 2 and 4 . The least gain was made by pigs on treatment 5 (all milo, $14 \%$ protein), this gain being significantly less than that made by pigs on ration treatments 1 and 3 .

The pigs fed an all-corn ration (grain portion) required the least feed to produce a pound of gain. However, only $0.05 \mathrm{lb}$. more feed was required to produce a pound of gain with treatment 3 , the ration which had a grain ratio of $1 / 3$ corn and $2 / 3$ milo. This difference was not statistically significant. The pigs fed these rations required significantly less feed per pound of gain than pigs on ration treatment 5 .

\section{TABLE 4. RATIOS OF CORN AND GRAIN SORGHUM FOR GROWING- FINISHING SWINE ${ }^{\text {a }}$}

(Experiment 2)

\begin{tabular}{|c|c|c|c|c|c|}
\hline Treatment & 3 & 1 & 2 & 4 & 5 \\
\hline Ration designation & $\begin{array}{l}5 / 3 \text { corn } \\
2 / 3 \text { milo }\end{array}$ & $\begin{array}{c}\text { All } \\
\text { corn }\end{array}$ & $\begin{array}{l}2 / 3 \text { corn } \\
1 / 3 \text { milo }\end{array}$ & $\begin{array}{c}\text { All } \\
\text { milo }\end{array}$ & $\begin{array}{c}\text { All } \\
\text { milo }\end{array}$ \\
\hline Calculated protein, $\%$ & 15.3 & 14.0 & 14.6 & 16.0 & 14.0 \\
\hline Pens per treatment, no. & 3 & 3 & 3 & 3 & 3 \\
\hline Pigs per pen, no. & 5 & 5 & 5 & 5 & 5 \\
\hline Av. initial wt., lb. & 47.9 & 47.5 & 47.7 & 47.6 & 47.6 \\
\hline Av. final wt., lb. & 178.1 & 173.6 & 171.3 & 170.8 & 167.8 \\
\hline Av, total gain, lb. & 130.2 & 126.1 & 123.6 & 123.2 & 120.2 \\
\hline Av. daily gain, lb. ${ }^{b}$ & 1.86 & 1.80 & 1.77 & 1.76 & 1.72 \\
\hline Feed per lb. gain, lb. ${ }^{b}$ & 3.63 & 3.58 & 3.81 & 3.78 & 3.97 \\
\hline
\end{tabular}

a Duration of test, 70 days.

b Means underlined by the same line are not significantly different at $P=0.05$ or less.

Although the results of the two all-milo treatments were not significantly different, there was a tendency for the $16 \%$ protein ration (treatment 4 ) to produce greater and more economical gains than the $14 \%$ protein ration (treatment 5). This would appear to indicate that the amount and kind of protein supplement is more critical in a sorghum ration than in a corn ration. That is, when formulating swine rations with grain sorghums, the higher protein content of grain sorghum, as compared with corn, may increase the opportunity for an amino acid deficiency or imbalance because less total supplemental protein (animal or plant) is required to provide a given protein level. This has been shown clearly by the research of Hillier et al. (1954, 1955, 1956) and Hillier (1957) who reported that lysine is probably the first limiting amino acid in milo rations since milo is lower than corn in lysine and there is less supplemental protein as a source of lysine in milo rations. 


\section{Summary}

Two hundred and twenty-four pigs were used to compare corn $(8.5 \%$ and $11 \%$ protein) with grain sorghums for growing-finishing swine. Although the greatest average daily gain was made by the pigs fed $8.5 \%$ protein corn, the difference between those fed corn and certain of the grain sorghums was not significant. The smallest gains were made by pigs fed $11 \%$ protein corn and the grain sorghum Hybrid RS 610. In general, it required approximately 0.2 to $0.7 \mathrm{lb}$. more feed to produce a pound of gain with grain sorghums than with corn, depending upon the variety fed.

When corn and milo were fed alone or in combination at different proportions the greatest average daily gains were made by the pigs fed a ration composed of $1 / 3$ corn and $2 / 3$ milo (grain portion). The least gains were made by those fed an all milo, $14 \%$ protein ration. Gains on the allmilo ration increased as the level of protein was increased from $14 \%$ to $16 \%$, but were still significantly less than the gains made on a combination of $1 / 3$ corn and $2 / 3$ milo.

Pigs fed an all-corn ration required the least feed per pound of gain; but, only $0.05 \mathrm{lb}$. more feed per pound gain was required by pigs fed the $1 / 3$ corn $-2 / 3$ milo ration. Significantly more feed was required per pound of gain with an all-milo, $14 \%$ protein ration.

\section{Literature Cited}

Aubel, C. E. 1950. The comparative value of corn and sorghum grains as swine fattening feeds. Kan. Agr. Exp. Sta. Circ. 265. p. 37.

Aubel, C. E., and A. F. Swanson. 1951. Testing the comparative palatability of different sorghums. Kan. Agr. Exp. Sta. Circ. 273. p. 6.

Aubel, C. E. 1954. The comparative value of corn and whole and ground milo with antibiotics as swine feeds. Kan. Agr. Exp. Sta. Circ. 308. p. 54.

Aubel, C. E. 1955. The comparative value of corn and whole and ground milo as swine fattening feeds. Kan. Agr. Exp. Sta. Circ. 320. p. 24.

Aubel, C. E. 1956. Comparative value of corn and whole and ground milo as swine fattening feeds. 7. Kan. Agr. Exp. Sta. Circ. 335. p. 84.

Baker, M. L, and C. F. Reinmiller. 1939. Feeding sorghum grain to growing and fattening pigs. Nebr. Agr. Exp. Sta. Bul. 323.

Frey, Kenneth J. 1951. The interrelationship of proteins and amino acids in corn. Cereal Chem. 28:123.

Hillier, J. C., Robert MacVicar and Wilson Pond. 1954. Grain sorghum as a feed for swine. Okla. Agr. Exp. Sta. Misc. Pub. MP-34. p. 94.

Hillier, J. C., Robert MacVicar and S. A. Ewing. 1955. Supplements to milo rations for swine. Okla. Agr. Exp. Sta. Misc. Pub. MP-43. p. 77.

Hillier, J. C., Robert MacVicar, S. A. Ewing and Willis Nickelson. 1956. Protein supplements to milo rations for swine. Okla. Agr. Exp. Sta. Misc. Pub. MP-45. p. 62.

Hillier, J. C. 1957. Amino acid supplements to milo rations for swine. Okla. Formula Feed Conference. p. 31.

Hillier, J. C., R. W. MacVicar and Wilson Pond. 1957. Levels of protein and protein supplements to milo rations for swine. Okla. Exp. Sta. Misc. Pub. MP-48. p. 94.

Loeffel, W. J. 1957. Grain sorghums as feeds for beef cattle and hogs. Nebr. Agr. Exp. Sta. Bul. 439.

Snedecor, G. W. 1956. Statistical Methods (5th ed.). The Iowa State College Press, Ames, Iowa. 